\title{
FIRST MOLECULAR CHARACTERIZATION OF THE PARTIAL COAT PROTEIN AND 3'UTR GENES RELATED TO DASHEEN MOSAIC VIRUS ON FLAMINGO FLOWERS (ANTHURIUM SPECIES) IN THE MEDITERRANEAN COAST OF TURKEY
}

\author{
KoÇ, G. \\ Subtropical Fruits Research and Experimental Center, Çukurova University, Adana, Turkey \\ (e-mail:gkmnkoc@hotmail.com.tr) \\ (Received $7^{\text {th }}$ May 2019; accepted $16^{\text {th }}$ Jul 2019)
}

\begin{abstract}
Observations were carried out on Anthurium sp growing at Mediterranean region (Adana, Mersin and Antalya provinces) of Turkey in 2015-2017. During the studies virus-like symptoms in plants; systemic chlorotic mosaic and irregular uniformity on leaf and petals were recognized. Eleven of 73 samples showed positive response with the Potyvirus group specific antibodies and their results were also confirmed by RT-PCR. The 327 bp products via using the Potyvirus-specific primers, MJ1 and MJ2 were run in $1.5 \%$ agarose gel. Further amplifications were made with the 3'UTR and 3'end of the coat protein of the viral genome. RT-PCR analysis using the primer MJ1 and M4T resulted in an amplification of 719 bp amplicon. Direct sequencing of RT-PCR products and BLAST results have showed that there were two clades between 96-99\% among the Mediterranean coast DsMV isolates. The data are available in Genebank with accession Number MK758088/Antalya; MK758087/Yenice). DsMV infection on Anthurium $s p$, was determined serologically and molecularly. To our knowledge, this is the first molecular record describing the occurrence, distribution and genome organisation of DsMV isolates that have been infecting Flamingo flowers at the Mediterranean coast of Turkey. Findings may have shown an evidence about uncontrolled distribution from Northern corner to Southern side.
\end{abstract}

Keywords: DsMV, potygroup serology, RT-PCR, molecular agroecology, evolution

\section{Introduction}

Flamingo flowers (Anthurium plants) are native to Central and South America. Anthurium belongs to the Alismatales ordo, Araceae family, Anthurium genus. It is known to have over 500 species. It is grown both to be sold as a potted plant and cut flower. The most grown species are Anthurium crystallinum, Anthurium veitchii, Anthurium magnificum, Anthurium scherzerianum and Anthurium andreanum. Among the species of Anthurium, Anthurium scherzerianum is the most cultivated species. As a result of various hybridization studies of this species, different colors were produced. Mostly Anthurium andreanum species are produced as cut flowers. The Anthurium plant in Turkey is cultivated in the Marmara, Aegean and Mediterranean regions. The nice plant has 8-15 cm diameter flesh-like flower tray, reproductive organ and 40-70 cm length flower on stem. Flamingo flower shows tropical plants' characters. Therefore, they require high levels of humidity, temperature and shading. Due to the climate requirements, it has been cultivated under cover in the Mediterranean, Aegean and Marmara regions of Turkey.

Like in the case of other ornamental plants, many diseases have been reported in its cultivation areas. For example; members of the Tospovirus, Nepovirus, Potyvirus and Cucumovirus species are among the most important viral factors causing damage and loss due to their infections on ornamental plants (Sutic et al., 1999; Daughtrey et al., 1997; Loebenstein et al., 1995). Such as Cucumber mosaic virus (CMV), Dasheen mosaic virus (DsMV) (Rivas et al., 1997; Miura et al., 2013) and Tomato spotted wilt 
virus (TSWV) (Fidan et al., 2016; Norman and Ali, 2012; Chen et al., 2003; Uchida et al., 1999). The species of ornamental plants belongs to family Areceae (Aroid) which are the most important hosts of Dasheen mosaic virus (DsMV). DsMV attacks at least 16 genera including Aglaonema, Caladium, Dieffenbachia, Philodendron and Zantedeschia genuses. Colocasia, Xanthosoma, Cyrtosperma species are also prone to infection with the virus (Nelson, 2008).

DsMV, has a narrow range to the plants of Aroid family (Brunt et al., 1996), the DsMV has been transmitted through tainted sap and via non-persistent manner by a couple of aphid species, including Myzus persicae, Aphis gossypii and Aphis craccivora (Buddenhagen et al., 1970). And also DsMV is not transmitted via seed propagation. The disease fundamentally causes tainted planting material which is the most common symptom. If vegetatively propagated cultivated plants have infection, it results in tainted flowers (Zettler et al., 1970; Van der Meer, 1985).

Investigation on commercial Flamingo flower plants have shown mosaic, chlorotic line indications in the veins of many plant leaves. They hindered the growth of the plant and were found to cause deformities in the nodes with color changes in the blossoms. The pathogen causing the symptoms has characterized as Dasheen mosaic infection (DsMV). The Philodendron verrucosum plant is a good lesion host for DsMV (Tooyoma, 1975). The other six Philodendron species tested and have deliberately contaminated with virus infection and showed diverse mosaic effects. Pale colored spots were found in Anthurium scandens the leaves of the cv violaceum plant. Further deformation of blossoms as well as the color quality of the knot were observed (Chagas et al., 1993). The DsMV infection results in deterioration of the appearance and nature of the blossoms. The mosaic, deformity and little protuberance indications of Anthurium $s p$. $c v$. river have been related with the Dasheen mosaic potyvirus and isolated the agent (Chagas et al., 1993).

If physical and molecular properties are focused on The DsMV, it is $750 \mathrm{~nm}$ in length and 11-13 nm wide which has flexuous, non-enveloped particles (De Brot and Ordosgoitti, 1974). The viral genome includes a monopartite single-stranded (ss) molecule of positive sense RNA of about $10 \mathrm{kbp}$, which contains $5^{\prime}$ and $3^{\prime}$ terminal UTRs flanking an imperative single ORF and the 3' UTR finishing with a poly-A tail (Hull, 1994; Adams et al., 2005; Ha et al., 2008; Cuevas et al., 2012). The ten utilitarian proteins in their solicitation from $5^{\prime}$ to $3^{\prime}$ are P1 (1st protein), Helper Component-Pro (accomplice fragment protease), P3 (3rd protein), 6K1, CI (barrel molded thought protein), 6K2, VPg (genome-associated), NIa-Pro (genuine protease of minimal nuclear fuse protein - NIa), NIb (broad nuclear consolidation protein) and (CP) coat protein (Colinet et al., 1998; Adams et al., 2005; Cuevas et al., 2012; Hull, 1994).

Essentially, plants that gave signs were subjected to Enzyme Linked Immuno Sorbent Assay (ELISA) testing utilizing DsMV polyclonal antisera and gave a negative outcome. ELISA tests with potyvirus monoclonal antiserum PTY 1, a particular antiserum explicit to the potyviral coat protein region, gave a positive response. ELISA is the most convenient procedure for routine distinguishing proof of DsMV in huge amounts of plant tests with variable contamination titres. Nevertheless, DsMV IgG is in limited facility, and the exceedingly thick concentrate of aroid sap is represented to intrude with ELISA tests (Rodoni and Moran, 1988). Moreover, past examination exhibited that recognizable proof of DsMV by ELISA was clashing obviously due to uneven course of DsMV (Hu et al., 1994). Serological investigation of potyviruses is routinely mismatched, due to immunological cross-reactions among species (Brunt, 
1992) and biological identification is extremely unbalanced. On the other hand, continuous advances in nucleic acid advances have enabled the improvement of stunning acknowledgment and recognizing proof instruments.

The currently accepted criteria for detecting disease species in the Potyviridae family are based on the collection of genomic information. Moreover, differentiation in host range and host reaction, antigenic properties and the morphology of inclusion bodies can be considered as criteria for limiting (King et al., 2012; Babu et al., 2011). In the same study, the 327-bp part of the coat protein gene area from the contaminated Colocasia esculenta plant, which has whitepox symptoms, has researched by Reverse Transcriptase Polymerase Chain reaction (RT-PCR) technique utilizing primers specific to the Potyviruses. DNA sequence investigation and BLAST examination demonstrated a close association with DsMV. Similarly, the presence of Dasheen mosaic infection (DsMV-Sc) has been verified on Spiranthes cernua plants that show chlorotic spots and mosaic indications (Guaragna et al., 2006).

The conspicuous confirmation was reliant on the Polymerase Chain Reaction, which was used for Potyvirus (Langeveld et al., 1991). Grisoni et al. (2006) has been used Potyvirus group specific primers for recognizable evidence of Potyvirus tainting Vanilla. Same researchers reported primer pair MJ1 and MJ2, which amplify a short fragment (327 bp centered on coat protein gene) of an extensive part of the potyviruses.

In the Mediterranean Region of Turkey, which has an important place in the production of ornamental plants, the studies of viral diseases started on the demands of the producers of Flamingo flower cultivations as interior and cut flowers. The symptoms; systemic chlorotic mosaic and irregular uniformity on leaf and petals) were considered to be related to Dasheen mosaic virus. As the production areas are usually intertwined with undergrowth vegetable production areas, it has been investigated in terms of viral diseases which are problem in both vegetable and ornamental plants.

Therefore, aims of the studies were to clarify the recognition and recognizable proof of the Potyvirus species tainting Flamingo flower (Anthurium sp.), through sequencing of fractional coat protein gene and the 3'UTR area of the viral genome. Then, the nearness of DsMV in Flamingo flower plants will be recognized by DAS-ELISA and RT-PCR systems. Finally, the CP and 3'UTR of some DsMV isolates will be sequenced in molecular genetic for distinguishing proof. The study may be the broadest research on DsMV in recent years at Turkey.

\section{Materials and methods}

Experiments have been set in Antalya, Mersin and Adana cities located at the Mediterranean region of Turkey (Fig. 1). Seventy-three samples from symptomatic Flamingo flower plants showing common DsMV symptoms (upward leaf curling, mosaic, yellowing, distortion and flower mosaics) and some asymptomatic leaf samples were used in molecular analyses (Fig. 2).

\section{Serological tests}

Collected samples were labelled and placed into plastic packs, then were conveyed to the Virology Lab via putting them in ice pail and kept at $4{ }^{\circ} \mathrm{C}$. All samples were used within $24 \mathrm{~h}$. 


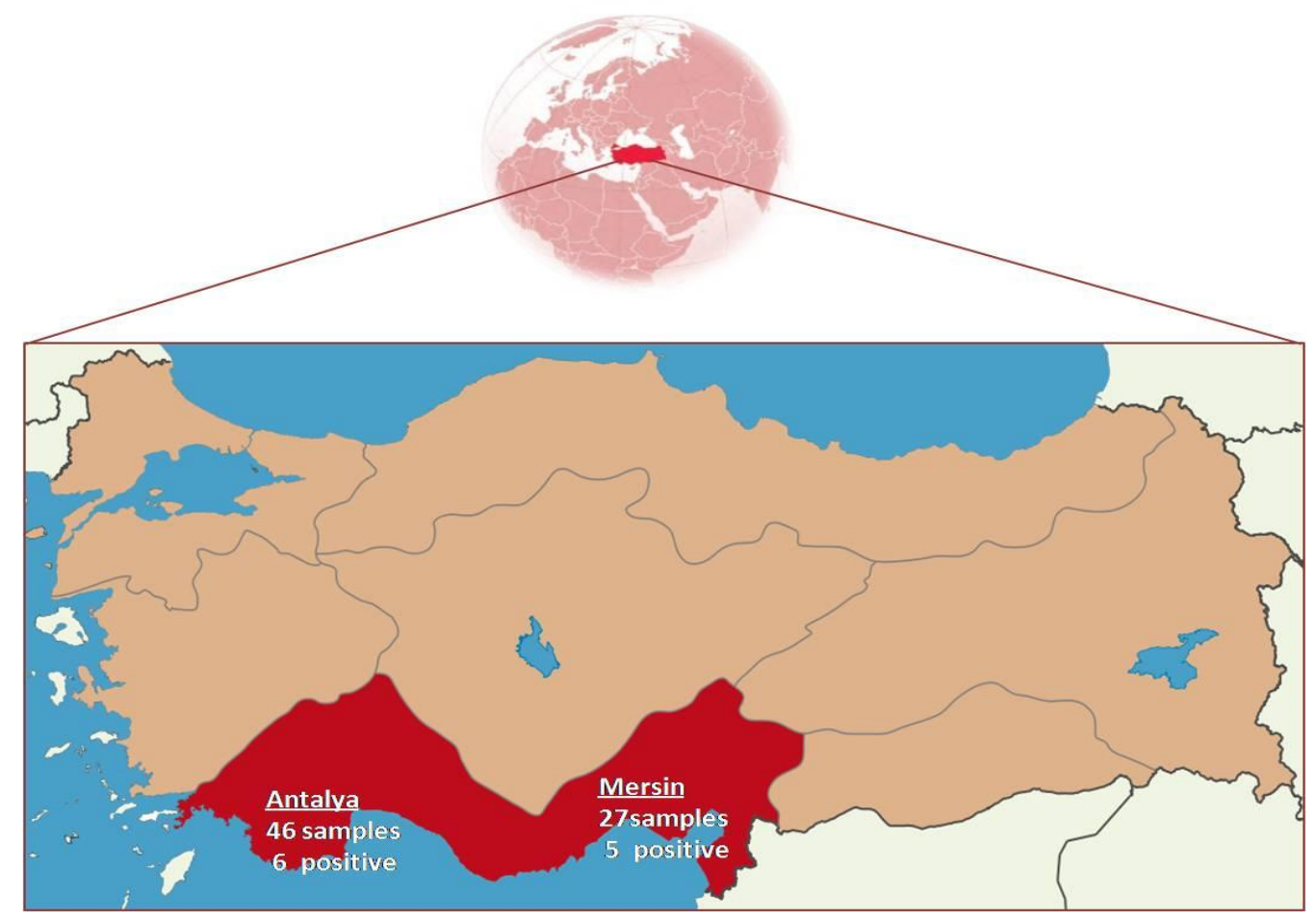

Figure 1. The map of the Mediterranean region in Turkey with positive locations (https://tr.wikipedia.org/wiki/Akdeniz_Bölgesi)
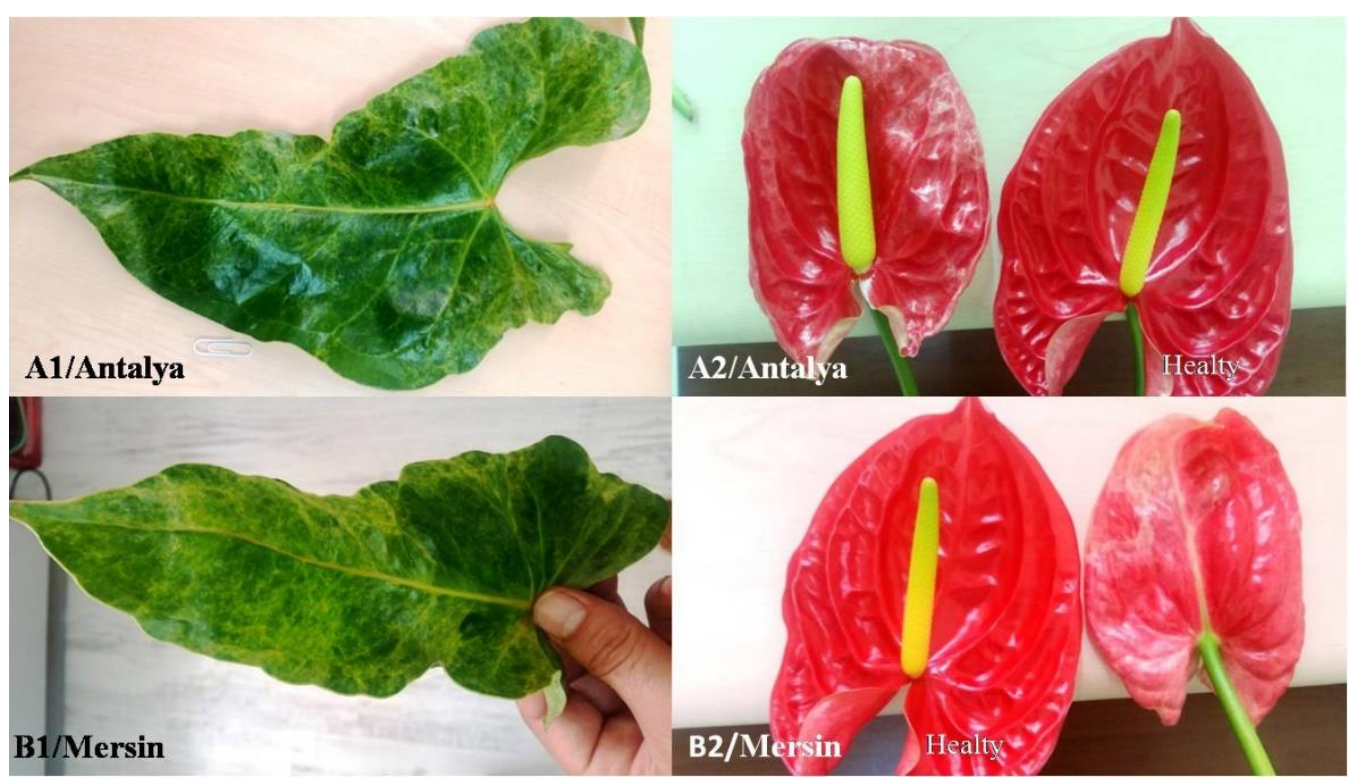

Figure 2. Athurium plants have showing typical DsMV symptoms (upward leaf curling, mosaic, yellowing, distortion and flower mosaics)

\section{Enzyme linked immunosorbent assay}

For distinguishing evidence infections contaminating Flamingo flower, leaves were attempted through ELISA utilising polyclonal antiserum specific to infections. The ELISA tests contained various virus species which are found in ornamental plants. All 
the tested polyclonal antibodies were given in Table 1. ELISA antisera one by one received from Agdia U.S. and Bioreba AG, Switzerland. Tests covered location of infections in tainted fresh leaves and conveyed according to Clark and Adams (1977). To each well of ELISA plates (Nunc F96 Maxisorp) $200 \mu \mathrm{l}$ of IgG diluted in coating buffer (BIOREBA antisera 1: 1000 ratio or Agdia antisera 1: 200 ratio) was added and they were incubated for $4 \mathrm{~h}$ at $30{ }^{\circ} \mathrm{C}$. The ELISA plate was washed with wash buffer and left for $3 \mathrm{~min}$, which was repeated 3 times. Samples prepared with extraction buffer were incubated for $16 \mathrm{~h}$ at $4{ }^{\circ} \mathrm{C}$ by adding $200 \mu$ of positive and negative controls to each well. The ELISA plate was washed again as described in the second step. IgG diluted 1: 1000 (Bioreba) and 1: 200 (Agdia) in conjugated buffer was incubated at $30{ }^{\circ} \mathrm{C}$ for $4 \mathrm{~h}$ by adding $200 \mu \mathrm{l}$ to each well and the ELISA plate was washed again as described in the second step. Subsequently, $200 \mu$ of the substrate solution $(1 \mathrm{mg} / \mathrm{ml}$ paranitrophenylphosphate) was added to each well and allowed to stand at room temperature in the dark for $1 \mathrm{~h}$.

The results were obtained by observing the formation of yellow color in the ELISA reader and measuring the absorbance values at $405 \mathrm{~nm}$ wavelength. Samples that gave at least twice the absorbance value of the healthy control value were considered infected or positive. Values close to positive but not definite were considered suspicious.

\section{Nucleic acid based assays}

We focus on DsMV in molecular studies because serologically positive results were obtained by Potyvirus genus-specific antibodies (Agdia). Moreover, the most obvious disease in Flamingo flower is DsMV and typical symptoms in the collected samples indicate DsMV.

\section{Total RNA isolation and reverse-transcription polymerase chain reaction ( $R T-P C R)$}

Total nucleic acid was extracted from contaminated Flamingo flower plants according to Dellaporta et al. (1983) and their RNAs were used in ReverseTranscriptase Polymerase Chain Reactions (RT-PCR). In the first place the samples were prepared from different tissues of infected Anthuriums such as Leaf, Petal, stamen + pistil, Peduncle or stem due to covering causal disease agent.

\section{RT-PCR detection of $C P$ region by $M J 1$ and $M J 2$}

Sense MJ1 (5'-ATGGTHTGGTGYATHGARAAYGG-3' and MJ2 (5'TGCTGCKGCYTTCATYTG-3') designed by Marie-Jeanne et al. (2000) (Fig. 3). Grisoni et al. (2006) published a single letter code H: A/C/T $\backslash, \mathrm{Y}: \mathrm{C} / \mathrm{T}, \mathrm{R}: \mathrm{A} / \mathrm{G}, \mathrm{K}: \mathrm{G} / \mathrm{T}$ that amplify a $327 \mathrm{nt}$ fragment in the CP gene of potyviruses of DsMV isolates. The cDNAs were obtained using Thermo Sci. Verso 1-Step RT-PCR Kit pack according to producer's manual. DsMV PCR mix was replicated by program through a cycle of RT at $49{ }^{\circ} \mathrm{C}$ for $45 \mathrm{~min}(\mathrm{~m}), 94{ }^{\circ} \mathrm{C}$ for $2 \mathrm{~min}$; following 38 cycles of $94{ }^{\circ} \mathrm{C}$ for $30 \mathrm{~s}, 50{ }^{\circ} \mathrm{C}$ for $55 \mathrm{~s}$., extension $72{ }^{\circ} \mathrm{C}$ for $55 \mathrm{~s}$, and a final step of $72{ }^{\circ} \mathrm{C}$ for $10 \mathrm{~min}$ in a thermal cycler (Babu et al., 2011).

Amplification of partial coat protein gene and 3'UTR; The universal primer sequence M4T, which trigers to the 3'end of the potyviral gene and the reverse primer in combination with the forward primer MJ1 were used. The RT-PCR was performed in a $20 \mathrm{~mL}$ volume. Each primers MJ1 and M4T-5'GTTTTCCCAGTCACGACTTTTTTTTTT-3' are shown in (Fig. 3). The RT-PCR mix 
was subjected to thermal programme: RT at $48^{\circ} \mathrm{C}$ for $45 \mathrm{~min}$, denaturation at $94{ }^{\circ} \mathrm{C}$ for $2 \mathrm{~min}$; 38 cycles of $94{ }^{\circ} \mathrm{C}$ for $30 \mathrm{~s}$, annealing. at $50{ }^{\circ} \mathrm{C}$ for $55 \mathrm{~s}$ and extension at $72{ }^{\circ} \mathrm{C}$ for $55 \mathrm{~s}$, and last step of $72{ }^{\circ} \mathrm{C}$ in 10 at thermal cycler (Babu et al., 2011).

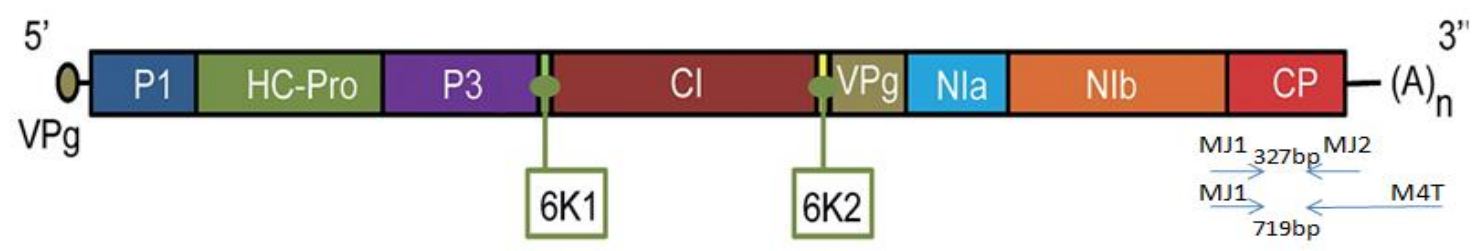

Figure 3. Schematic representation of Potyvirus genome (Cuevas et al., 2012) and the primers' amplicon ranges for DsMV Mediteranean isolates in this study

\section{Analysis of RT-PCR products}

$10 \mu \mathrm{l}$ of PCR product was utilized within gel loading buffer and dissected on a $1.5 \%$ agarose gel containing $0.5 \mathrm{mg} / \mathrm{ml}$ of ethidium bromide (Sambrook et al., 2001). $100 \mathrm{bp}$ DNA stepping ladder (thermo) was also used on each gel to compare PCR products' size.

\section{Phylogenetic analysis}

The DsMV containing RT PCR products obtained by MJ1 and MT4 primer sequences and dnasp5 program was conducted. Phylogenetic analyses were performed by MEGA 7 software and neighbour joining process, according to conventional analysis. Obtained sequences were compared with strains of DsMV genebank (NCBI, National Center for Biotechnology Information). Sequences from the accessions (accession Number MK758088/Antalya; MK758087/Yenice) were considered. Sequence alignment of the DsM virus isolates and homology between sequences were calculated according to Thompson et al. (1994). A sequence identity matrix of the 3'UTR region and partial CP gene of the DsMV isolates were constructed using the BIOEDIT with worldwide DsMV sequences obtained from the GeneBank.

\section{Results}

\section{Type of symptoms on Anthurium sp.}

Upward leaves curling, mosaic, yellowing, distortion and mosaic flower associated with Flamingo flower plants were indicating DsMV symptoms (Fig. 2). Virus infected leaves in the fields were light yellow and leaf margin areas resembled to distortion (Fig. 2A1-A2); There were leaf mosaics reduced in size and shapeless malformated leaves (Fig. 2A1-A2). General flower discoloration was observed and petals had mild whitish mosaics on the Flamingo plants (Fig. 2B1-B2).

\section{Occurrence of viruses by serology (ELISA)}

Immunological assay performed in ELISA serological tests: they were individually repeated at least two times to approve presence of the virus. 11 out of 73 samples have given positive reactions (with $15.06 \%$ incidence) with the potyvirus genus group 
specific antiserum. The 11 positive samples of Flamingo flowers were collected from 2 provinces, 6 of them were from Antalya and other 5 were from Yenice, Mersin, Turkey (Fig. 2).

Further verification tests have applied RT-PCR with total nucleic acids isolated from the samples following ELISA tests. Due to having positive result to Potyvirus group, any positive reaction for other tested virus species and groups, cellar DsMV symptoms and not in laboratory opportunities of DsMV commercial antiserum. As well DsMV is previously reported on many aroid species (Nelson, 2008).

\section{The RT-PCR amplification}

For confirming the serology test results, RT-PCR analyses were conducted. DsMV; 327 bp sections as the objective RNA have been put in CP focal areas and DsMV; 719 bp on 3'UTR and coat protein partial genes, are identical for detection experiments. Selected MJ1-MJ2 were published as degenerate primers by different researchers (Chen et al., 2001; Pappu et al., 1993; Langeveld et al., 1991). For the reason of couple of these primers good at for RT-PCR based detection.

Extracted RNAs (327 nt) were chosen symptomologically from two samples, and they yielded expected products (Fig. 4) on agarose gel (1.5\%) electrophoresis. The RTPCR results affirmed DsMV in Flamingo plants.

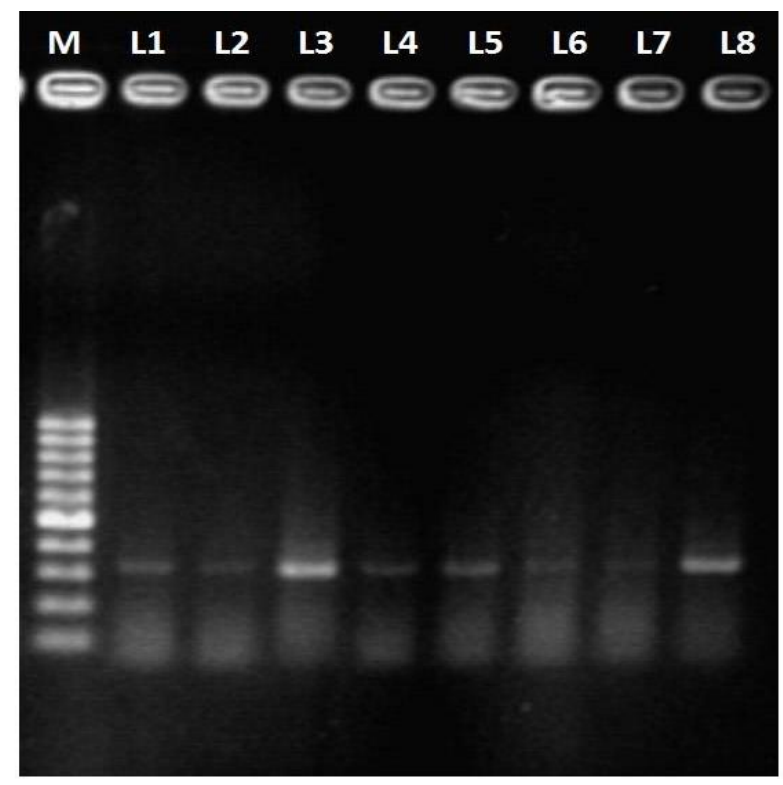

Figure 4. First lane M DNA ladder; RT-PCR products of 327 bp of DsMV CP on agarose gel (1.5\%) (Lane1, A1 Leaf; L2, A2 Petal; L3, A2 stamen + pistil; Lane4, A2 Peduncle or stem; Lane 5, B1 Leaf; Lane 6, B2 Petal; Lane 7, B2 stamen + pistil; Lane 8, B2 Peduncle or stem) positive Flamingo flower samples (" $A$ " coded samples from Antalya and " $B$ " coded samples from Yenice/Mersin of Mediterranean Cost in Turkey)

Additionally, conserved CP central regions resulted bands in RT-PCR analysis using primer pairs combination of MJ1 and M4T. We obtained $719 \mathrm{bp}$ cDNA bands of DsMV located between partial CP and 3'UnTranslated Region verifying discrimination of different isolates in RT-PCR system (Fig. 5). The 3'UTR sequences of potyviruses have an opportunity for understanding different isolates (Frenkel et al., 1989; Pappu et al., 1993). 


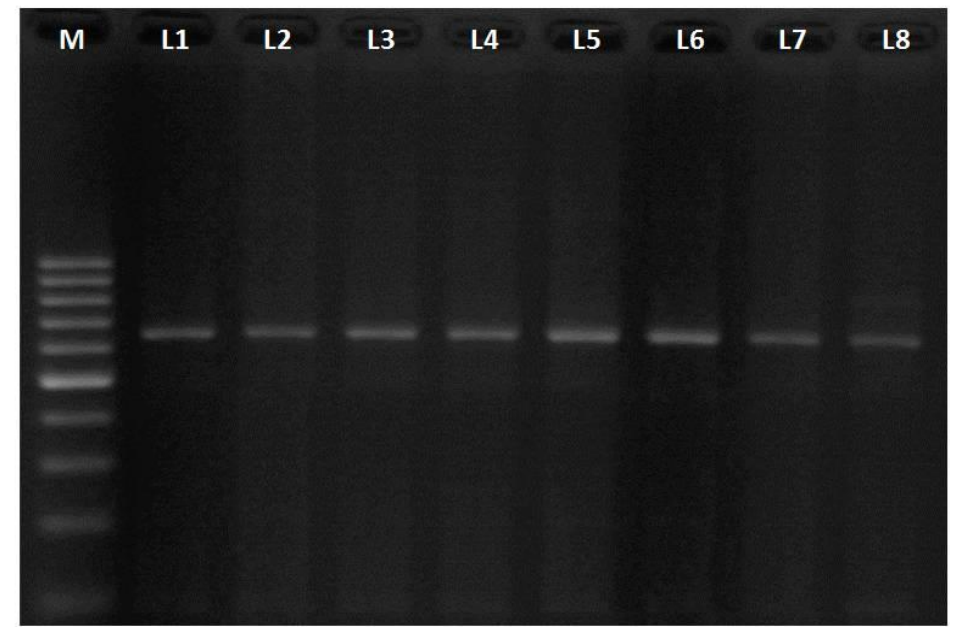

Figure 5. RT-PCR product of 719 bp of DsMV CP on agarose gel (1.5\%); First lane, M DNA ladder; Lane1, A1 Leaf; L2, A2 Petal; L3, A2 stamen + pistil; Lane4, A2 Peduncle or stem; Lane5, B1 Leaf; Lane 6, B2 Petal; Lane 7, B2 stamen + pistil; Lane 8, B2 Peduncle or stem) positive Flamingo flower samples ("A" coded samples from Antalya and " $B$ " coded samples from Yenice/Mersin of Mediterranean Coast in Turkey

ELISA tests were conducted against 20 viruses where two types of group specific antiserums were used. Positive results were obtained only against Potygroup specific polyclonal antiserums and $327 \mathrm{nt} \mathrm{CP}$ core regional primers by RT-PCR (Fig. 4) among all viruses infected samples (Table 1). In addition to the species specific ELISA tests, Tospo group specific antiserums did not give any positive results for all collected samples. RT-PCR resulted $719 \mathrm{nt}$ amplicon that was specific for DsMV. There were additional results found from different plant tissues; leaf; petal; stamen + pistil and peduncle or stem (Fig. 5).

\section{Phylogenetic analysis}

Phylogenetic analysis was performed by MEGA 7 programming, entire DsMV sequences were distinguished (Fig. 6). Two distinct haplotypes which were symptomologically chosen from Anthurium sp plants at Mediterranean region of Turkey were determined from present DsMV isolates by either RT-PCR or sequences. Two different but not so significantly distinct haplotypes have been analyzed in NCBI system and their sequences were submitted to NCBI as new records.

The Flamingo flower samples from Turkey in Genebank have accession numbers MK758088/Antalya and MK758087/Yenice. The accession numbers were first recorded to NCBI system (Fig. 6) and they listed with other isolates from worldwide in Table 2. The two isolates of DsMV have approximately $99.49 \%$ similarity with each other isolate in Turkey. They were replaced in two clades as they were isolated from two Anthurium species. This is may be caused by two production materials imported from different origins. Phylogenetic tree showed that both isolates are related with each other at the Mediterranean region of Turkey. Their sequences were clarified that two Anthurium sp DsMV isolates from the Mediterranean region of Turkey have similar homology with Xanthosoma sp Et56 from Ethiopia (Accession Num. MG602233.1) and Colocosia esculenta TW from Japan: Utsunomiya (Accession Num. AJ298036.1) isolates. 
The DsMV from Flamingo flower Antalya, Turkey isolates (accessed as new record to NCBI system with accession number: MK758088) (100\%-Turkey) have showed approximately $91.40 \%$ similarity with Japan: Utsunomiya (Accession Num.AJ298036.1) isolate and 90.54\% Nicaragua NiNG1 (Accession Num.AM910398.1); 87.32\%. Tanzania Xanthosoma sp. Tz24 (Accession Num.MG602242.1) around the world (Table 2; Fig. 6; Table 3). The other DsMV isolate, Yenice was reported to NCBI system with accession number: MK758087 (99.49\%-Turkey). The DsMV Yenice has approximately $89.54 \%$ similarity with Xanthosoma sp Et56 from Ethiopia (Accession Num. MG602233.1) isolate and 84.55\% New Zealand Taro DsMV1 (Accession Num.AY994104.1); 83.50\% French Polynesia Vanilla tahitensis FP (WP013, Accession Num. AJ616719.1) (Table 2; Fig. 6; Table 3, respectively).

The developmental history was derived utilizing the Neighbor-Joining technique. The ideal tree with the aggregate of branch length $=24.38716469$ is appeared. The level of recreate trees in which the related taxa bunched together in the bootstrap test (1000 repeats) are appeared at the branches. The tree is attracted to scale, with branch lengths in indistinguishable units from those of the evolutionary distances used to deduce the phylogenetic tree (Fig. 6).

Table 1. Serological and molecular studies and results of Flamingo flower plant samples

\begin{tabular}{|c|c|c|c|c|}
\hline \multirow[t]{2}{*}{ Virus species } & \multirow[t]{2}{*}{ Plant species } & \multirow[t]{2}{*}{ Assays } & \multicolumn{2}{|c|}{$\begin{array}{c}\text { Number of samples } \\
\text { *Result }\end{array}$} \\
\hline & & & 27/Yenice & 46/Antalya \\
\hline ArMV (Arabis Mosaic Virus) & Anthurium sp & ELISA & - & - \\
\hline SLRSV (Strawberry Latent Ringspot Virus) & Anthurium sp & ELISA & - & - \\
\hline TRSV (Tobacco Ringspot Virus) & Anthurium sp & ELISA & - & - \\
\hline ToRSV (Tomato Ringspot Virus) & Anthurium sp & ELISA & - & - \\
\hline TMV (Tobacco Mosaic Virus) & Anthurium sp & ELISA & - & - \\
\hline TRV (Tobacco Rattle Tobravirus) & Anthurium sp & ELISA & - & - \\
\hline TNV (Tobacco Necrosis Virus) & Anthurium sp & ELISA & - & - \\
\hline ToMV (Tomato Mosaic Virus) & Anthurium sp & ELISA & - & - \\
\hline PepMoV (Pepper Mottle Potyvirus) & Anthurium sp & ELISA & - & - \\
\hline Tospo (Tospovirus) & Anthurium sp & ELISA & - & - \\
\hline TSWV (Tomato Spotted Wilt Virus) & Anthurium sp & ELISA & - & - \\
\hline Poty (Genus group Poty Virus) & Anthurium sp & ELISA & $5+$ & $6+$ \\
\hline PVY (Potato Virus Y) & Anthurium sp & ELISA & - & - \\
\hline AMV (Alfalfa Mosaic Virus) & Anthurium sp & ELISA & - & - \\
\hline ZYMV (Zucchini Yellow Mosaic Virus) & Anthurium sp & ELISA & - & - \\
\hline BCMV (Bean common mosaic potyvirus) & Anthurium sp & ELISA & - & - \\
\hline LMV (Lettuce mosaic potyvirus) & Anthurium sp & ELISA & - & - \\
\hline PVX (Potato Virus X) & Anthurium sp & ELISA & - & - \\
\hline INSV (Impatiens necrotic spot virus) & Anthurium sp & ELISA & - & - \\
\hline TuMV (Turnip Mosaic Potyvirus) & Anthurium sp & \begin{tabular}{|l|} 
ELISA \\
\end{tabular} & - & - \\
\hline DsMV (Dasheen mosaic virus). & Anthurium sp & RT-PCR & $5+$ & $6+$ \\
\hline CMV (Cucumber Mosaic Virus) & Anthurium sp & ELISA & - & - \\
\hline
\end{tabular}

*(-) Negative (not infected); (+) Positive (infected) 
Table 2. The Anthurium sp DsMV isolates in Turkey, which are ranked in phylogenetic tree

\begin{tabular}{c|c|c|c|c|c}
\hline No & $\begin{array}{c}\text { Accession } \\
\text { num. }\end{array}$ & Isolate name & Host & Country & $\begin{array}{c}\text { Per } \\
\text { ident. }\end{array}$ \\
\hline 1 & MK758088 & Antalya & Anthurium sp. & Turkey & - \\
\hline 2 & MK758087 & Yenice & Anthurium sp. & Turkey & $99.49-$ \\
\hline 3 & KJ786965.1 & T10 & $\begin{array}{c}\text { Amorphophallus } \\
\text { paeoniifolius }\end{array}$ & India & 99.59 \\
\hline 4 & MG602229.1 & Et26 & Colocasia esculenta & Ethiopia & 90.65 \\
\hline 5 & AJ298036.1 & TW & Colocosia esculenta & Japan: Utsunomiya & 91.40 \\
\hline 6 & LC114515.1 & Ds23 & Amorphophallus konjac & Japan: Gunma, Shibukawa & 90.95 \\
\hline 7 & DQ925466.1 & DsMV-VN/Tt1 & Typhonium trilobatum & Viet Nam: Hanoi & 90.66 \\
\hline 8 & MG602233.1 & Et56 & Xanthosoma sp & Ethiopia & 89.54 \\
\hline 9 & AM910398.1 & NiNG1 & & Nicaragua & 90.54 \\
\hline 10 & AJ298033.1 & M13 & Zantedeschia aethiopica & China: Zhejiang & 89.54 \\
\hline 11 & MG602235.1 & Ug31 & Xanthosoma sp. & Uganda & 87.95 \\
\hline 12 & KY242359.1 & & Colocasia esculenta & USA: Hawaii Strain (II) & 87.91 \\
\hline 13 & KT372699.1 & ZAN & Zantedeschia sp. & Taiwan & 88.24 \\
\hline 14 & KP729477.1 & $66 / 14$ & Zantedeschia sp. & Bosnia and Herzegovina & 90.19 \\
\hline 15 & AY994104.1 & DsMV1 & Taro & New Zealand & 84.55 \\
\hline 16 & KY242358.1 & & Colocasia esculenta & USA: Hawaii Strain I & 84.38 \\
\hline 18 & AY994105.2 & DsMV2 & Taro & New Zealand & 84.40 \\
\hline 19 & MG602242.1 & Tz24 & Xanthosoma sp. & Tanzania & 87.32 \\
\hline 20 & AJ616719.1 & FP (WP013) & Vanilla tahitensis & French Polynesia & 83.50 \\
\hline
\end{tabular}

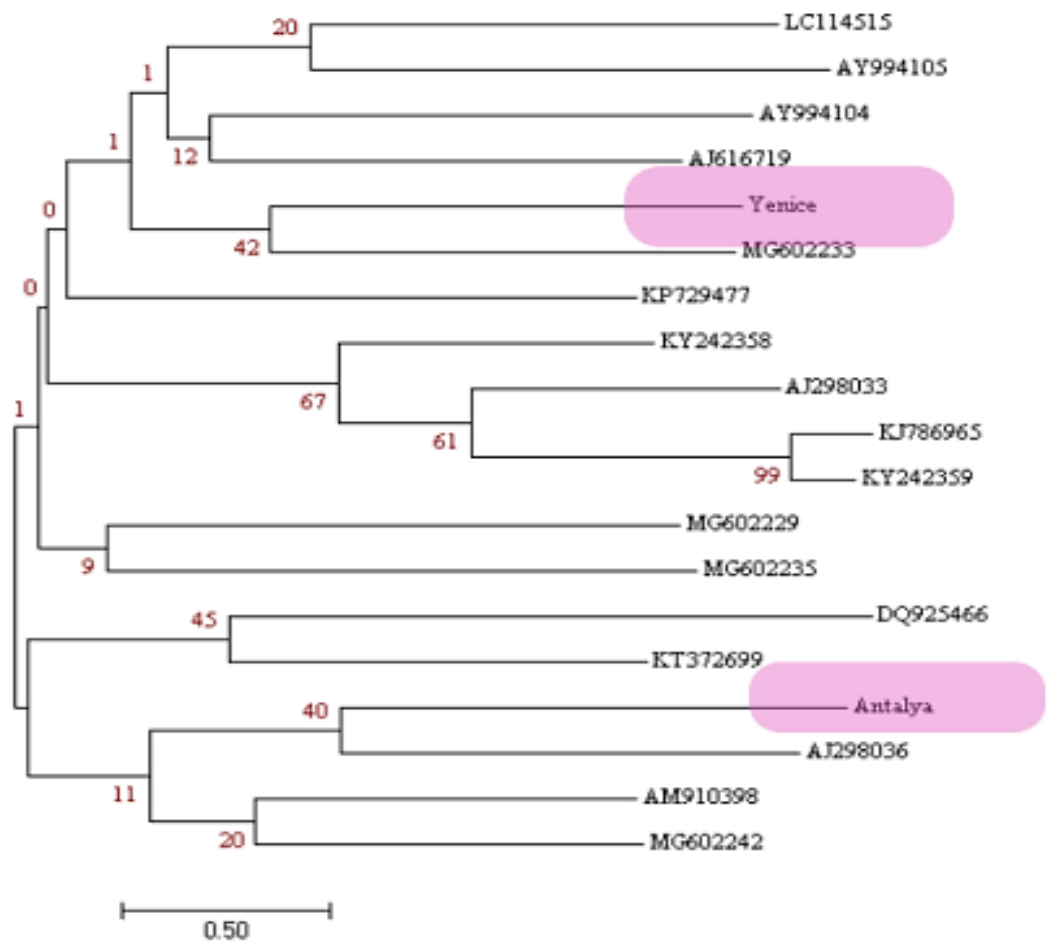

Figure 6. Phylogenetic tree of two different DsMV isolates from Mediterranean region of Turkey were clustered within the GenBank database (detailed in Table 2) 
Table 3. Phylogenetic tree pair wise distance matrix of DsMV haplotypes of different countries and Turkey (Antalya and Yenice)

\begin{tabular}{|c|c|c|c|c|c|c|c|c|c|c|c|c|c|c|c|c|c|c|}
\hline Yenice & & & & & & & & & & & & & & & & & & \\
\hline Antalya & 4.62 & & & & & & & & & & & & & & & & & \\
\hline KJ786965 & 3.15 & 4.95 & & & & & & & & & & & & & & & & \\
\hline MG602229 & 2.72 & 3.39 & 2.80 & & & & & & & & & & & & & & & \\
\hline АJ298036 & 4.61 & 2.32 & 5.08 & 3.97 & & & & & & & & & & & & & & \\
\hline LC114515 & 3.12 & 4.08 & 3.06 & 3.00 & 3.01 & & & & & & & & & & & & & \\
\hline MG602233 & 2.25 & 4.33 & 2.76 & 4.50 & 3.44 & 3.23 & & & & & & & & & & & & \\
\hline AJ298033 & 4.52 & 4.52 & 1.51 & 4.21 & 3.28 & 3.42 & 3.00 & & & & & & & & & & & \\
\hline DQ925466 & 4.70 & 3.34 & 4.21 & 3.41 & 3.87 & 4.15 & 2.97 & 3.33 & & & & & & & & & & \\
\hline AM910398 & 2.90 & 2.96 & 3.10 & 3.25 & 1.80 & 2.63 & 4.28 & 2.82 & 3.37 & & & & & & & & & \\
\hline MG602235 & 3.06 & 2.95 & 4.39 & 2.79 & 3.53 & 3.22 & 2.63 & 2.68 & 4.66 & 2.61 & & & & & & & & \\
\hline KT372699 & 2.76 & 3.36 & 2.47 & 2.89 & 4.33 & 4.57 & 2.71 & 3.31 & 2.54 & 2.86 & 2.79 & & & & & & & \\
\hline KY242359 & 3.26 & 4.40 & 0.35 & 3.12 & 4.81 & 3.12 & 2.78 & 1.85 & 4.15 & 2.52 & 4.37 & 4.33 & & & & & & \\
\hline KP729477 & 2.96 & 3.39 & 4.48 & 2.71 & 3.50 & 3.08 & 3.01 & 3.11 & 3.29 & 3.35 & 3.32 & 2.93 & 3.27 & & & & & \\
\hline AY994104 & 2.99 & 2.99 & 3.33 & 3.62 & 3.47 & 3.09 & 2.73 & 4.35 & 3.23 & 4.01 & 3.15 & 2.81 & 3.07 & 3.17 & & & & \\
\hline KY242358 & 3.52 & 3.84 & 1.86 & 3.23 & 3.09 & 2.97 & 2.89 & 1.46 & 4.44 & 2.22 & 2.66 & 2.92 & 2.90 & 2.63 & 3.36 & & & \\
\hline AY994105 & 3.43 & 2.88 & 3.47 & 3.01 & 3.99 & 2.37 & 2.74 & 3.56 & 4.44 & 3.29 & 3.33 & 4.92 & 2.90 & 3.19 & 2.84 & 4.53 & & \\
\hline AJ616719 & 2.43 & 3.41 & 4.41 & 3.11 & 3.10 & 3.08 & 3.07 & 3.05 & 4.05 & 2.71 & 3.44 & 3.19 & 3.43 & 2.66 & 2.44 & 2.75 & 2.40 & \\
\hline MG602242 & 2.49 & 3.90 & 4.32 & 3.25 & 2.52 & 2.08 & 3.25 & 3.45 & 3.45 & 1.84 & 3.52 & 2.99 & 4.35 & 3.26 & 3.44 & 2.17 & 3.44 & 3.04 \\
\hline
\end{tabular}

\section{Discussion}

The sanitary status of Dasheen viruses in Turkey has not been broadly studied. Therefore, in the project, we aimed to determine and identify how to detect the virus and possibly control economically important viruses associated with Flamingo flower.

Typical symptomatic Flamingo flower plants in this study, were tested with ELISA and RT-PCR analyses. 73 samples were collected from Mersin and Antalya provinces in the in Mediterranean region: among which 11 were positive with the potyvirus infection in ELISA and RT-PCR similarly to previous works (Kibar, 2014; Kidanemariam, 2016, 2018)

In our study frame, virus infected leaves in the fields were light yellow and leaf margin areas resembled distortion, leaves having mosaics reduced in size and shapeless, malformated leaves were observed, flowers had discoloration and petal mosaics were also observed on flamingo plants. The same was found in the case of several aroids (Elliott et al., 1997; Lima et al., 2004; Nelson, 2008; Cabrera et al., 2010; Babu and Hegde, 2014). Infrequently, yellow and green patterns occurred over the whole leaf surface, which may have seemed slender with a distorted edge (Kohler et al., 1997).

In a close study, an excessive strain of DsMV caused pale green and yellowish designs on stunted and extremely distorted leaves in French Polynesia (Jackson, 1982). A few of which can be decreased to strap-like structures without flaps. The presence of DsMV in Anthurium andreanum (Flamingo blossom) and a few orchid (Cymbidium spp.) species was just investigated by means of serological methods. DsMV was verified in two Anthurium andreanum leaf samples in Trace location of Turkey (Kibar, 2014). Similarly, Greber and Shaw (1986) diagnosed Dasheen mosaic virus (DsMV) via mechanical inoculation of plant sap and serological tests in wild and cultivated plant species. Also close results, reported by Simone and Zettler (1990) that there are hosts of DsMV in a few different tropical plants besides Araceae family ornamental flora. Viral 
agents belonging to the genera Tospovirus, Nepovirus, Potyvirus and Cucumovirus had been among the main viral agents inflicting loss of ornamental plants which were reported (Daughtrey et al., 1997; Loebenstein et al., 1995; Sutic et al., 1999).

The Flamingo flower samples, in Mersin (Yenice) and Antalya, gave positive reactions (with 15.06\% incidence) against the potyvirus genus group specific antiserum but there were not any serological reactions against other tested viruses and groups. Likewise, Lima et al. (2004) reported that their collected samples from 20 symptomatic Anthurium flowers were revealed positive results in ELISA. Our results were consistent with the potyvirus specific antiserum in ELISA but negative response obtained with the antiserum for CMV. Only difference between the above study and ours were antisera which we did not have DsMV antiserum.

Valverde et al. (1997) reported DsMV in Dasheen vegetation, which was produced in in vitro environment. DsMV was determined by means of ELISA check in distinctive forms of Colocasia esculenta plant in different researches (Hu et al., 1994; Rodrigues et al., 1984; Zettler et al., 1987; De Brot and Ordosgoitti, 1974). Kibar (2014) reported the DsMV serologically by ELISA on Anthurium and Cymbidium flowers. Shukla et al. (1992) referenced a couple of challenges related to serological identification of some potyviruses, which were direct result of characteristic complexities related with the potyvirus coat proteins (Shukla and Ward, 1989a, b; Ward and Shukla, 1991). Shukla et al. (1994) expressed that the complexities came about because of 3 overwhelming inconveniences. Those are especially in the first place variable cross-reactivity of potyvirus antisera; in second placeamazing and conflicting combined pursuing; and in the third place absence of cross-response between certain strains.

ELISA and molecular assays have been used for the detection of DsMV by different papers (Abo El-Nil et al., 1977; Nelson, 2008; Babu and Hegde, 2014), both techniques are sensitive for the detection of viruses but RT-PCR is more reliable with high selectivity to detect such viruses (Randles et al., 1996).

Among molecular analyses of this study, the RT-PCR have been intensified with degenareted primers MJ1-MJ2 and 327 bp target fragments were obtained for the detection of DsMV. Based on many previous results (Chen et al., 2001; Pappu et al., 1993; Langeveld et al., 1991) MJ1-MJ2 were selected which were reported as degenerate for the DsM virus from different aroid isolates. The $327 \mathrm{bp}$ fragments as the target RNA have been amplified for both potygroup and DsMV due to highly conserved CP core central regions. Similarly, Marie-Jeanne et al. (2000) reported a 327 bp fragment in the Coat Protein genes of potyviruses. Since they amplify a short part and gave superior enhancement signals in preliminary experiments of diverse isolates DsMV isolates Marie Jeanne et al. (2000) also concluded similar results with DsMV. 719 bp on coat protein partial genes and 3'UTR, were resulted for specific detection and discriminations.

Likewise, Babu et al. (2011) clarified the $327 \mathrm{bp} \mathrm{CP}$ fragments from the infected Colocasia esculenta plants via RT-PCR. The processing of unique primers particular to the Potyviruses and cDNA sequence evaluation confirmed for DsMV.

As well Grisoni et al. (2006) applied Potyvirus group specific primers for recognizable proof of Potyvirus contaminating Vanilla plants. The primer pair MJ1 and MJ2 explicitly amplify a brief piece $(327 \mathrm{bp}$ ) of the middle district of coat protein gene of a big portion of the potyviruses.

In Addition to $327 \mathrm{bp}$ region amplification; primer pairs combination of MJ1 and M4T were studied for $719 \mathrm{bp}$ cDNA bands of DsMV to compare the isolates with 
worldwide isolates via ncbi database in project scope. RT-PCR sequences of $719 \mathrm{bp}$ affirmed the diseases for DsMV positive plants from East Mediterranean isolates in ELISA. The amplified PCR 719 bp products were applied for sequencing and phylogenetic tree discrimination. No critical differences was observed among the plant tissues when the RT-PCR was applied. That is identical to the result obtained on exceptional tissues in agarose gel electrophoresis in our study. Frenkel et al. (1989) and Pappu et al. (1993) decided that the 3'UTR sequences of potyviruses were useful for differentiation of strains and species of potyviruses

Edited DsMV sequences from East Mediterranean isolates were compared with strains of gen bank (NCBI). Sequences of The Mediterranean region isolates of Turkey were edited as accession Number MK758088/Antalya and MK758087/Yenice for the first time in Turkey (Fig. 6).

The main outcome from analysis of sequence revealed that DsMV Yenice (Mersin) and Antalya isolates were most similar to both in itself and all the other compared geographically originated isolates. In the same way, Babu et al. (2011) compared 3'UTR region of different isolates by universal primers MJ1 and M4T and also they identified DsMV was closely related to DeSLK2 isolate. Finally, same papers reported DsMV as the first report of molecular based detection of the DSMV infecting Amorphophallus paeoniifolius in India. Briefly, it was determined that the 3'UTR sequences of potyviruses had an opportunity that benefited for differentiation of isolates (Frenkel et al., 1989; Pappu et al., 1993).

Similarly, Zavareh et al. (2013) determined the DsMV in Anthurium plant by means of PCR method. Furthermore, it is reported that the Areceae family is a few of the most essential hosts of Dasheen mosaic virus (DsMV) in ornamental plant species Nelson (2008).

In another group of studies, presence of DsMV with molecular techniques was detected by Reyes et al. (2009) in a tropical plant Cocoyam (Xanthosoma spp.); Babu et al. (2011) in Colocasia esculenta, and Chen and Adams (2001) identified the complete genome sequences of an isolate of Dasheen mosaic virus (DsMV) in Zantedeschia aethiopica. Likewise, Maino (2003) concluded the variability within the coat proteinCR of DsMV isolates from French Polynesia, Papua New Guinea, Vietnam Solomon Islands, Samoa, and New Caledonia via amplifying, cloning and sequencing. In comparison with the DsMV sequences at the database, the most variability changed into taken as $21.9 \%$, while the center district of the CP become analysed, while the greatest variability dropped to $6 \%$. Additionally, equivalent guide was demonstrated, most variability become present in the $\mathrm{N}$ end.

Li et al. (1998) ordinarily cloned and sequenced the 3' - terminal 3158 nts of the Caladium isolate of (DsMV-Ch). The sequences included the 3' end of the Nia, Nib and CP-coding regions and a $246 \mathrm{nt}$ UTR (with the exception of the poly-A tail) in the long run. The comparisons of DsMV-Ch CP with that of DsMV-LA and DsMV-TEN isolates found a closeness of $84-88 \%$ on the nucleotide level, and $92-94 \%$ at the amino acid level. When all data considered an arrangement of the amino acid sequencing of the 3 isolates discovered $\mathrm{N}$ terminal variability and a close similarity among the DsMV-Ch and DsMV-TEN. 


\section{Conclusion}

The Mediterranean region of Turkey is a critical agricultural cultivation area for many types of plants grown. Ornamental vegetation has a vital importance inside the production of cultivated crops which contribute substantially to the financial system and have an excessive export capacity.

Decorative plants' leaves and cut flowers are the most common wealth of ornamental plant market in global scale. Productivity and quality losses occur because of adverse outcomes of diseases in decorative flowers that economic importance is increasing day by day. Especially in practice, there is no chemical application to control virus diseases. Consequently, the virus diseases can restrict the production via reducing flower production within the Mediterranean region of Turkey. It should be understood to apply control measures and their epidemiology and molecular origin ought to be known.

Studying the Anthurium sp. as cut flower species in greenhouses (Flamingo plant) becomes important for economical reasons. Viral disease agents have reduced their market value and their aesthetic value for consumers.

Natural distribution and occurrence of Dasheen viruses in the studied area have determined as very limited distribution in Turkey. Our results have already mentioned above sanitary situations in Flamingo flowers growing regions are very vitally important in Turkey. As well as, to prevent the spreading of common plant viruses and DsMV is only possible with the detection of the agent. All of DsMV positive samples in this study have already been eradicated. Therefore, maintaining Turkey's disease free status with the definite destruction of the inoculum sources needs controlled quarantine applications. Probably, DsMV's insect vectors, are actually second main factors, are responsible for the epidemiology by re-infection in the green houses. Insecticide applications are commonly used technique for management strategy against aphids (Knauss et al., 1975; Monge et al., 1987; Valverde et al., 1997). Even it is one of the main threatening elements to the ecology and environment. Resistant cultivars and sanitation should be used for control of the DsMV in practices. Sometimes resistance breaking isolates can be developed in greenhouses (Fidan and Sar1, 2019). Infected plants, presence of vectors and presence of virus have vital effects on the spread of DsMV at infected areas (Çolak Ateş et al., 2018).

Some potyvirus isolates, such as Alfalfa Mosaic Virus (AMV), Zucchini Yellow Mosaic Virus (ZYMV) and Plum Pox Potyvirus (PPV), etc.) are highly infectious and are able to transmit with aphids. They have been studied and molecularly characterised from different hosts both in Turkey and in Cyprus (important for material exchange) (Özer et al., 2012; Fidan et al., 2012; Koç, 2010; Koç and Baloğlu, 2006).

Therefore, molecular epidemiology should be well understood and spread to field or outdoor plants should be prevented. In addition, the presence of broad range vector aphids in the greenhouses and outside, and the lack of biological and more ecologically friendly chemical protection, the risk of infection increases that will allow DsMV to spread more by aphids from cultivated plant crops. It also originates progressively from different weed species and occurs after infection with infected seedlings or inoculum sources if it is not well controlled.

This is the first molecular event report of DsMV in Anthurium sp in the Mediterranean region of Turkey. Our results have shown reliable laboratory molecular methods with immunological ELISA and molecular RT-PCR analyses. Further advanced techniques such as Next Generation Sequencing should be used to confirm our results. Due to the fact that DsMV have been transmitted not only by aphids but also 
by infected material and cuttings, certified plant materials, eradication and vector management are powerful strategies to overcome the DsMV disease. Otherwise, the disease transmitted to the open field rotates with vectors in every season and returns as an epidemiological threat of agroecological origin.

This paper additionally indicates that uncontrolled distribution of infected ornamental plants between countries will allow the spread of plant viruses. In the present paper RT- PCR was a standardized method for reliable detection of DsMV. The results have also revealed that all exported plant materials should be distributed with certain quarantine regulations.

The harvest should be made with sterilized cutting equipments by the practitioners. Otherwise, if eradication or sterilization rules are not followed, infection may spread to more plants and areas. Mechanical harvesting might cause more spread of DsMV than vector transmission in time. Moreover, correct decoding of molecular epidemiology codes may open new doors to the fight against DsMV. Deep impacts on the ecological environment can be prevented provided that virus vector relationships are understood correctly. Therefore, more detailed and multidisciplinary studies should be focused. Moreover, these studies should not only be limited to in vivo, but also projects that can be applied in vitro.

Acknowledgements. Thanks to Assist. Prof. Ozer Çalış, Dr. Hakan Fidan and MSc. Nuray Sarı for the critical review of the publication.

Conflict of interests. The author declares that he has no conflict of interests.

Ethical approval. This article does not contain any studies with human participants or animals performed by any of the authors.

\section{REFERENCES}

[1] Abo El-Nil, M. M., Zettler, F. W., Hiebert, E. (1977): Purification, serology and some physical properties of dasheen mosaic vims. - Phytopathology 67: 1445-1450.

[2] Adams, M., Antoniw, J., Fauquet, C. (2005): Molecular criteria for genus and species discrimination within the family Potyviridae. - Arch. Virol. 150: 459-479.

[3] Babu, B., Hegde, V. (2014): Molecular characterization of dasheen mosaic virus isolates infecting edible aroids in India. - Acta Virologica 58: 34-42.

[4] Babu, B., Hegde, V., Makeshkumar, T., Jeeva, M. (2011): Characterisation of the coat protein gene of dasheen mosaic virus infecting elephant foot yam. - J. Plant Pathol. 93: 199-203.

[5] Brunt. A. A. (1992): The general properties of Potyviruses. - Arch Virol.;Supplementum 5: 3-16.

[6] Brunt, A. A., Crabtree, K., Dallwitz, M. J., Gibbs, A. J., Watson, L. (1996): Viruses of Plants. - Wallingford: CAB International; p. 1484.

[7] Buddenhagen, I. W., Milbrath, G. M., Hsieh, S. P. (1970): Virus diseases of Taro and other Aroids. - Proceedings of the Second International Symposium on Tropical Root and Tuber Crops 2: 53-55.

[8] Cabrera, D., González, J. E., Portal, O., Hernández, R. (2010): Influencia Del Virus Del Mosaico De La Malanga Sobre El Contenido De Clorofilas En Xanthosoma Nigrum (Vell.) Genotıpo Inivit M 95-1. - Rev. Protección Veg. 25(3): 194-196.

[9] Chagas, C. M., Colariccio, A., Galleti, S. R., Kitajima, E. W. (1993): Natural infection of Amorphophallus konjac with Dasheen mosaic virus in Brazil. - Fitopatologia Brasileira 18(4): 551-554. 
[10] Chen, J., Adams, M. J. (2001): Molecular characterisation of an isolate of dasheen mosaic virus from Zantedeschia aethiopica and comparisons in the genus potyvirus. - Archives of Virology 146: 1821-1829.

[11] Chen, J., McConnell, D. B., Henny, R. J., Everitt, K. C. (2003): Cultural Guidelines for Commercial Production of Interiorscape Anthurium. ENH956. - University of Florida, Gainesville.

[12] Clark, M. R., Adams, A. N. (1977): Characteristics of the microplate method of enzymelinked immunosorbent assay for the detection of plant viruses. - J. Gen. Virol. 34: 475483.

[13] Çolak Ateş, A., Fidan, H., Büyüköztürk, D., Torun, H., Dinçer, D., Yüzbaşığlu, E. G. (2018): Studies on the determination of diseases, pests and weeds in leafy vegetables in eastern Mediterranean region. - 4th International Agriculture Congress 05-08 July, 2018.

[14] Colinet, D., Nguyen, M., Kummert, J., Lepoivre, P., Xia, F. Z. 1998 Differentiation among Potyviruses infecting sweet potato based on genus- and virus specific reverse transcription polymerase chain reaction. - Plant Dis. 82: 223-9.

[15] Cuevas, J. M., Delaunay, A., Visser, J. C., Bellstedt, D. U., Jacquot, E., Elena, S. F. (2012): Phylogeography and molecular evolution of potato virus Y. - PLoS One 7: e37853.

[16] Daughtrey, M. L., Jones, R. K., Moyer, J. W., Daub, M. E., Baker, J. R. (1997): Tospoviruses Strike the greenhouse industry: INSV has become a major pathogen on flower crops. - Plant Disease. 81(11): 1220-1230.

[17] De Brot, E. A., Ordosgoitti, A. (1974): Dasheen mosaic virus infection of Colocasia and Xanthosoma in Venezuela. - Plant Disease Reporter 58: 1032-1034.

[18] Dellaporta, S. L., Wood, J., Hicks, J. B. (1983): A plant DNA mini-preparation: version 2. - Plant Mol Biol Rep. 1(4): 19-21.

[19] Elliott, M. S., Zettler, F. W., Brown, L. G. (1997): Dasheen Mosaic Potyvirus of Edible and ornamental Aroids. - Plant Pathol. Circular 384. Dept. Agric. \& Consumer Services, Florida.

[20] Fidan, H., Sari, N. (2019): Molecular characterization of resistance breaking tomato spotted wilt virus (TSWV) isolate medium segment in tomato. - Applied Ecology and Environmental Research 17(2): 5321-5339.

[21] Fidan, H., Adak, N. A., Konuksal, A., Akerzurumlu, E., Y1lmaz, M. A. (2012): Occurrence of alfalfa mosaic virus (Amv) diseases on potato crops in northern Cyprus. Acta Hort. (ISHS) 960: 341-346.

[22] Fidan, H., Koç, G., Topçu, T. (2016): Tomato spotted wilt virus (TSWV) infection and molecular characterization in Anthurium sp (Anthurium sp.' de Tomato Spotted Wilt Virus (TSWV) Enfeksiyonu ve Moleküler Karakterizasyonu). - Alatarım 15(2): 28-36.

[23] Frenkel, M. J., Ward, C. W., Shukla, D. D. 1989. The use of 3'noncoding nucleotide sequences in the taxonomy of Potyviruses: application to Water Melon Mosaic Virus 2 and Soybean Mosaic Virus-N. - J Gen Virol. 70: 2775-2783.

[24] Greber, R. S., Shaw, D. E. (1986): Dasheen mosaic virus in Queensland. - Australasian Plant Pathology 15(2): 29-33.

[25] Grisoni, M., Moles, M., Farreyrol, K., Rassaby, L., Davis, R., Pearson, M. (2006): Identification of Potyviruses infecting vanilla by direct sequencing of a short RT-PCR amplicon. - Plant Pathol. 55: 523-9.

[26] Guaragna, M., Ndum, O., Jordan, R. (2006): Detection and characterization of two previously undescribed potyviruses in the terrestrial orchid Spiranthes cernua. - Acta Hart. 722. DOI: 10.17660/ActaHortic.2006.722.26.

[27] Ha, C., Revill, P., Harding, R. M., Vu, M., Dale, J. L. (2008): Identification and sequence analysis of potyviruses infecting crops in Vietnam. - Arch. Virol. 153: 45-60.

[28] Hu, J. S., Meleisea, S., Wang, M. (1994): Detection of dasheen mosaic virus from taro plants in the field and in tissue culture. - Plant Disease 78: 754. 
[29] Hull, R. (1994): Resistance to plant viruses: obtaining genes by non-conventional approaches. - Euphytica 75: 902-906.

[30] Jackson, G. V. H. (1982): A Virus disease of Taro in French Polynesia. - Report to the South Pacific Commission, Noumea.

[31] Kibar, H. (2014): Investigations on the determination of tomato spotted wilt virus (TSWV), dasheen mosaic virus (DSMV) and cucumber mosaic virus (CMV) in Yalova Province, Turkey (Yalova İli Kesme Çiçek Üretimi Yapılan Alanlarda Tomato Spotted Wilt Virus (TSWV), Dasheen Mosaic Virus (DSMV) ve Cucumber Mosaic Virus (CMV)'lerinin Saptanmasi Üzerine Araştırmalar). - T. C. Namık Kemal Üniversitesi Fen Bilimleri Enstitüsü Yüksek Lisans Tezi.

[32] Kidanemariam, D. B. (2018): Viruses of taro and other edible aroids in East Africa. - A thesis for the degree of Doctor of Philosophy, Queensland University of Technology Brisbane, Australia.

[33] Kidanemariam, D. B., Abraham, A. D., Sukal, A. C., Holton, T. A., Dale, J. L., James, A. P., Harding, R. M. (2016): Complete genome sequence of a novel zantedeschia mild mosaic virus isolate: the first report from Australia and from Alocasia sp. - Archives of Virology 161: 1079-1082.

[34] King, A. M., Adams, M. J., Lefkowitz, E. J., Carstens, E. B. (2012): Virus Taxonomy: Classification and Nomenclature of Viruses: Ninth Report of the International Committee on Taxonomy of Viruses. - Elsevier, Amsterdam.

[35] Knauss, J. F., Zettler, F. W., Conover, C. A. (1975): Field evaluation of caladiums derived from tissue culture. - Proc. Am. Phytopathol. Sot. 2: 69.

[36] Koç, G. (2010): Determination and characterization of plum pox potyvirus (PPV, Sharka) 'Situation in Stone fruit in eastern Mediterranean Region (Doğu Akdeniz Bölgesinde Sert Çekirdekli Meyvelerde Plum Pox Potyvirüs (PPV, Sharka)' Ünün Durumunun Belirlenmesi Ve Karakterizasyonu). - Çukurova Üniversitesi Fen Bilimleri Enstitüsü Dr. Tezi.

[37] Koç, G., Baloğlu, S. (2006): First report of sharka in the Çukurova region of Turkey. Journal of Plant Pathology 88: 65-67.

[38] Kohler, F., Pellegrin, F., Jackson, G., Mckenzie, E. (1997): Diseases of Cultivated crops in Pacific Islands Countries. - South Pacific Commission, Noumea, New Caledonia.

[39] Langeveld, S. A., Dore, J. M., Memelink, J., Derks, A. F. L. M., van der Vlugt, C. I. M., Asjes, C. J., Bol, J. F. (1991): Identification of potyviruses using the polymerase chain reaction with degenerate primers. - J Gen Virol. 72: 1531-41.

[40] Loebenstein G, Lawson, R. H., Brunt, A. A. (1995): Virus and Virus-Like Diseases of Bulb and Flower Crops. Chapter 1. - Wiley, New York, pp. 1-14.

[41] Li, R. H., Zettler. F. W., Purcifull, D. E., Hiebert, E. (1998): The nucleotide sequence of the 3 '-terminal region of dasheen mosaic virus (Caladium isolate) and expression of its coat protein in Escherichia coli for antiserum production. - Archives ofVirology 143: 2461-2469.

[42] Lima Roberto, C. A., Lima Albersio, J. A., Aguiar Rubens, J. (2004): Serological Identification of Dasheen mosaic virus in Anthurium sp. in the State of Ceará. - Fitopatol. Bras. 29(1): 105.

[43] Maino, M. K. (2003): The development of a serological-based diagnostic test for dasheen mosaic potyvirus (DsMV). - A thesis submitted for the degree of Master of Applied Science, Centre for Molecular Biotechnology, School of Life Sciences, Queensland University of Technology.

[44] Marie-Jeanne, V., Loos, R., Peyre, J., Alliot, B., Signoret, P. (2000): Differentiation of Poaceae potyviruses by reverse transcription polymerase chain reaction and restriction analysis. - J Phytopathol. 148: 141-51.

[45] Miura, N. S.; Beriam, L. O. S., Rivas, E. B. (2013): Detection of Cucumber mosaic virus in commercial Anthurium crops and genotypes evaluation. - Horticultura Brasileira 31: 322- 327. 
[46] Monge, M., Arias, O., Ramirez, P. (1987): Obtencion de plantas de tiquisque blanco (Xanthosoma sugittifolium) de tiquisque morado (X. oioluceum) y de iampi (Colocucia esculenta) libres de virus por medio del cultivo in vitro de apices. - Agron. Costarricense 11(1): 71-79.

[47] Nelson, S. C. (2008): Dasheen mosaic of edible and ornamental aroids. - Plant Disease CTAHR. http://www.ctahr.hawaii.edu/oc/freepubs/pdf/PD-44.pdf (accessed: January 23, 2012.

[48] Norman, D. J., Ali, G. (2012): Anthurium Diseases: Identification and Control in Commercial Greenhouse Operations. - UF/IFAS Extension, Gainesville. http://edis.ifas.ufl.edu.

[49] Özer, M., Sipahioğlu, H. M., Usta, M., Fidan, H. (2012): Cloning and sequencing of coat protein gene of zucchini yellow mosaic virus isolated from squash and muskmelon in Turkey. - Turk J Biol 36: 423-429. DOI: 10.3906/biy-1110-16.

[50] Pappu, S. S., Brand, R., Pappu, H.R, Rybicki, E. P., Gough, K. H., Frenkel, M. J., Niblett, C. L. (1993): A polymerase chain reaction method adapted for selective amplification and cloning of 3' sequences of potyviral genomes: application to Dasheen Mosaic Virus. Journal of Virological Methods 41: 9-20.

[51] Randles, J. W., Hodgson, R. A. J., Wefels, E. (1996): The rapid and sensitive detection of plant pathogens by molecular methods. - Australasian Plant Pathology 25: 71-85.

[52] Reyes G, Rönnberg-Wastljung, A. C., Nyman, M. (2009): Comparison of field performance between Dasheen mosaic virus free and virus infected in vitro plants of Cocoyam (Xanthosoma spp.) in Nicaragua. - Experimental Agriculture 42(3): 301-310.

[53] Rivas, E. B., Duarte, L. M. L., Alexandre, M. A. V., Galleti, S. R. (1997): Dasheen Mosaic Virus in Anthurium species. - Virus Reviews \& Research 2: 192-193.

[54] Rodoni, B. C., Moran, J. R. (1988): The detection of dasheen mosaic virus using the enzyme-linked immunosorbent assay (ELISA). - Acta Horticulturae 234: 281-285.

[55] Rodrigues, M. G. R., Kitajima, E. W., Lin, M. T. (1984): Mosaic of edible and ornamental Araceae caused by Dasheen Mosaic Virus. - Fitopatologia Brasileira 9: 291299.

[56] Sambrook, J., Russel, D. W. (2001): Molecular Cloning: A Laboratory Manual. 3rd Ed. Cold Spring Harbour Laboratory Press, Cold Spring Harbour.

[57] Shukla, D. D., Ward, C. W. (1989a): Structure of potyvirus coat proteins and its application in the taxonomy of potyvirus group. - Advances in Virus Research 36: 273314.

[58] Shukla, D. D., Ward, C. W. (1989b): Identification and classification of potyviruses on the basis of coat protein sequence data and serology. - Archives of Virology 106: 171200.

[59] Shukla, D. D., Lauricella, R., Ward, C. W. (1992): Serology of Potyviruses: Current Problems and Some Solutions. - In: Barnett, O. W. (ed.) Potyvirus Taxonomy. Springer, Wien, pp. 57-69.

[60] Shukla, D. D., Ward, C. W., Brunt, A. A. (1994): The Potyviridae. - CAB International, Wellington.

[61] Simone, G.W, Zettler, F.W (1990): Dasheen mosaic disease of araceous foliage plants. Plant Pathology. https://plantpath.ifas.ufl.edu/misc/media/factsheets/pp0042.pdf.

[62] Sutic, D. D., Ford, R. E., Tošić, M. T. (1999): Handbook of Plant Virus Diseases. - CRC Press, Boca Raton, FL.

[63] Thompson, J. D., Higgine, D. G., Gibson, T. J. (1994): CLUSTAL W: improving the sensitivity of multiple sequence alignment through sequence weighting, position specific gap penalties and weight matrix choice. - Nucleic Acids Res. 22: 4673-80.

[64] Tooyama, A. (1975): Indicator plants for dasheen mosaic virus. - Ann. Phytopathology. Soc. Japan 41: 504-505. 
[65] Uchida, J. Y., Ogata, D., Nagata, N. (1999): Tomato Spotted Wilt Virus on Anthurium. Plant Disease 17. Cooperative Extension Service, College of Tropical Agriculture and Human Resources, University of Hawaii at Manoa, Honolulu.

[66] Valverde, R., Gomez, L., Saborio, F., Torres, S., Arias, O., Thorpe, T. (1997): Field evaluation of dasheen mosaic virus-free cocoyam plants produced by in vitro techniques. - Scientia Horticulturae 68: 37-47.

[67] Van der Meer, F. W. (1985): Occurrence of dasheen mosaic virus in South Africa. Phytophylactica 17: 95-98.

[68] Ward, C. W., Shukla, D. D. (1991): Taxonomy of potyviruses: current problems and some solutions. - Intervirology 32: 269-296.

[69] Zavareh, N., Maleki, M., Ghotbi, T. (2013): Serological and molecular detection of Cucumber Mosaic Virus from two maincommercial Anthurium cultivars in Iran. - Annals of Biological Research 4(4): 120-125.

[70] Zettler, F. W., Hartman, R. D. (1987): Dasheen mosaic virus as a pathogen of cultivated Aroids and control of the virus by tissue culture. - Plant Dis. 71(1I): 958-962.

[71] Zettler, F. W., Foxe, M. J., Hartman, R. D., Edwarson, J. R., Christie, R. G. (1970): Filamentous Viruses infecting dasheen and other araceas plants. - Phytopathology 60: 983-987. 